\title{
Effectiveness of Harvest - Aid Defoliants and Environmental Conditions in High Density Cotton
}

\author{
Kancheti Mrunalini*, M. Sree Rekha and V.R.K. Murthy
}

Department of Agronomy, Agricultural College, Bapatla, 522101, Andhra Pradesh, India

*Corresponding author

\section{A B S T R A C T}

\begin{tabular}{|l|}
\hline K e y w o r d s \\
Boll opening \\
percentage, \\
Defoliation, Dropp \\
Ultra, Degree days, \\
Etherel
\end{tabular}

\section{Introduction}

Harvest-aid defoliants have been introduced to facilitate mechanical harvesting in cotton. Defoliants are chemicals that either impact plant hormonal activity related to leaf loss or cause direct injury to leaves, both at a level that promotes leaf drop (abscission) and often represents the final step in the production of a cotton crop.

The defoliation process usually completes in 7 to 10 days, but in some situations, it may be delayed for as long as 30 days (Cathey, 1986; Gwathmey and Hayes, 1997; Malik and Din, 1997). The success of defoliation process depends on the maturity of cotton crop and prevailing weather conditions at the time of application. Brown and Hyer (1956) reported that defoliant efficiency was associated with both the number of mature bolls and mature leaves at the time of chemical termination. The Night temperature of $16^{\circ} \mathrm{C}$ has been found most suitable for defoliation (Cathey, 1986). Cotton defoliation is often practiced when $60 \%$ of bolls are opened to avoid loss in yield and fibre quality (Snipes and Baskin, 1994).

The objectives of this research were to compare the effectiveness of defoliants in cotton and relate these effects to crop maturity and temperature regimes prevalent during and after treatments. 


\section{Materials and Methods}

The experiment was carried out at Agricultural College Farm, Bapatla, Andhra Pradesh, during kharif 2016. The soil of experimental field was clay in texture, slightly alkaline in reaction (7.64), low in organic carbon $(0.5 \%)$ and medium in available nitrogen $(219.5 \mathrm{~kg}$ $\left.\mathrm{ha}^{-1}\right)$, and phosphorus (25.2 $\left.\mathrm{kg} \mathrm{ha}^{-1}\right)$ and high in available potassium $\left(310.6 \mathrm{~kg} \mathrm{ha}^{-1}\right)$. The experiment was laid out in Randomized Block Design replicated thrice with nine treatments comprising of $\mathrm{T}_{1}$ - Dropp Ultra $540 \mathrm{SC}$ (Thidiazuron 360 + Diuron 180) @ $150 \mathrm{ml} / \mathrm{ha}$; $\mathrm{T}_{2}$ - Dropp Ultra $540 \mathrm{SC}$ (Thidiazuron $360+$ Diuron 180)@200 ml/ha; $\mathrm{T}_{3}$ - Etherel @ 1500 ppm; $\mathrm{T}_{4}$ - Etherel @ 2000 ppm; $\mathrm{T}_{5}$ Urea @ 10\%; $\mathrm{T}_{6}$ - Urea @ 15\%; $\mathrm{T}_{7}-\mathrm{NaCl} @$ 15\%; $\mathrm{T}_{8}-\mathrm{NaCl} @ 20 \% ; \mathrm{T}_{9}$ - Control. The chemical defoliants were applied as a foliar spray as per treatments when cotton crop attained 60 BOP. Control treatment was sprayed with water. Cotton variety, suraj was sown on 21 July 2016, at high density i.e., at inter-row spacing of $45 \mathrm{~cm}$ and intra-row spacing of $10 \mathrm{~cm}\left(2,22,222\right.$ plants ha $\left.{ }^{-1}\right)$.

Recommended cultural practices and plant protection measures were followed throughout the crop growing season. Cumulative degree days were calculated using base temperature of 10 and $5^{\circ} \mathrm{C}$ for kharif and rabi seasons, respectively.

\section{Results and Discussion}

Defoliation in cotton by using different defoliants and desiccants was influenced by various factors like type of chemical, rate of application, crop coverage, maturity of the plant and weather conditions. The crop completed its defoliation in 15 days after treatment imposition indicating that the temperature prevailing at the time of defoliant application played a significant role in inducing defoliation.
Minimum temperature of $16^{\circ} \mathrm{C}$ and a diurnal temperature of $24^{\circ} \mathrm{C}$ have been found critical for minimal leaf response to most defoliants (Cathey, 1985; 1986).

In this experiment, maximum $\left(32.1^{\circ} \mathrm{C}\right)$ and minimum $\left(17.7^{\circ} \mathrm{C}\right)$ temperatures that occurred during the fifteen days following defoliant treatment were above the threshold limits. Degree-days unit of more than $100^{\circ} \mathrm{C}$ days favours good defoliation in cotton. In the trial $270.7{ }^{\circ} \mathrm{C}$ days were received which hastened the defoliation process (Table 1).

At 3 days after defoliant application, there was a significant increase in percent defoliation $(19.4 \%)$ in Dropp Ultra 540 SC (Thidiazuron $360+$ Diuron 180)@200 ml ha ${ }^{-1}\left(\mathrm{~T}_{2}\right)$ which was on par with Dropp Ultra 540 SC (Thidiazuron 360 + Diuron 180) @ $150 \mathrm{ml} \mathrm{ha}$ ${ }^{1}\left(\mathrm{~T}_{1}\right)$ and Etherel @ 2000 ppm $\left(\mathrm{T}_{4}\right)$ and it was also significantly highest defoliation than remaining treatments (Table 2).

Application of Dropp Ultra 540 SC (Thidiazuron 360 + Diuron 180) @ $200 \mathrm{ml}$ $\mathrm{ha}^{-1}\left(\mathrm{~T}_{2^{-}} 99.7 \%\right)$ and Dropp Ultra $540 \mathrm{SC}$ (Thidiazuron 360+Diuron 180) @ $150 \mathrm{ml}$ $\mathrm{ha}^{-1}\left(\mathrm{~T}_{1}-93.1 \%\right)$ (Table 2) was found equally effective to induce defoliation at 15 days after defoliant spray. Thidiazuron accelerates boll dehiscence by increasing ethylene level in cotton leaves (Suttle, 1985). Light penetration is also improved by leaf removal. These crop conditions lead to early maturity and opening of bolls (Malik et al., 1991).

This implies that warm temperatures played dominant role to stimulate defoliation and boll opening processes. The role of crop maturity was of lesser degree than that of temperatures not withstanding differences in crop ontogeny. Cathey (1986) stated that condition of plant and prevailing weather at the time of application are the major factors that limit efficiency of defoliation process. 
Table.2 Percent defoliation $(\%)$ and seed cotton yield $\left(\mathrm{kg} \mathrm{ha}^{-1}\right)$ of cotton as influenced by application of different defoliants

\begin{tabular}{|c|c|c|c|}
\hline Treatments & $\begin{array}{l}\text { Percent defoliation ( } \% \text { ) } \\
\text { (At } 3 \text { Days after defoliant spray) }\end{array}$ & $\begin{array}{c}\text { Percent defoliation (\%) } \\
\text { (At } 15 \text { Days after defoliant } \\
\text { spray) }\end{array}$ & $\begin{array}{l}\text { Seed cotton } \\
\text { yield } \\
\left(\mathrm{kg} \mathrm{ha}^{-1}\right)\end{array}$ \\
\hline T - Dropp Ultra 540 SC (Thidiazuron 360 + Diuron 180) @ $150 \mathrm{ml} \mathrm{ha}^{-1}$ & 39.1 & 93.1 & 2212 \\
\hline $\mathrm{T}_{2}$ - Dropp Ultra 540 SC (Thidiazuron 360 + Diuron 180) @ $200 \mathrm{ml} \mathrm{ha}^{-1}$ & 60.0 & 99.7 & 2265 \\
\hline $\mathrm{T}_{3}$ - Etherel @ 1500 ppm & 12.5 & 68.0 & 2307 \\
\hline $\mathrm{T}_{4}$ - Etherel @ 2000 ppm & 16.6 & 71.6 & 2359 \\
\hline$T_{5}$ - Urea @ 10\% & 2.9 & 21.4 & 2064 \\
\hline $\mathrm{T}_{6}$-Urea@15\% & 4.5 & 7.1 & 2121 \\
\hline $\mathrm{T}_{7}-\mathrm{NaCl} @ \mathbf{1 5 \%}$ & 8.8 & 27.4 & 2058 \\
\hline $\mathrm{T}_{8}-\mathrm{NaCl} @ 20 \%$ & 12.8 & 43.8 & 1975 \\
\hline $\mathbf{T}_{9}-$ Control & 5.1 & 33.0 & 1829 \\
\hline SEm \pm & 1.32 & 4.23 & 126 \\
\hline $\mathrm{CD}(0.05)$ & 3.9 & 12.7 & 379 \\
\hline CV $(\%)$ & 20.3 & 13.6 & 10.2 \\
\hline
\end{tabular}

Table.3 Quality parameters of cotton as influenced by application of different defoliants

\begin{tabular}{|l|}
\multicolumn{1}{|c|}{ Treatments } \\
\hline $\mathrm{T}_{1}$ - Dropp Ultra 540 SC (Thidiazuron 360 + Diuron 180) @ $150 \mathrm{ml} \mathrm{ha}^{-1}$ \\
\hline $\mathrm{T}_{2}$ - Dropp Ultra 540 SC (Thidiazuron 360 + Diuron 180) @ $200 \mathrm{ml} \mathrm{ha}^{-1}$ \\
\hline $\mathrm{T}_{3}$ - Etherel @ 1500 ppm \\
\hline $\mathrm{T}_{4}$ - Etherel @ 2000 ppm \\
\hline $\mathrm{T}_{5}$ - Urea @ 10\% \\
\hline $\mathrm{T}_{6}$ - Urea @ 15\% \\
\hline $\mathrm{T}_{7}$ - NaCl @ 15\% \\
\hline $\mathrm{T}_{8}$ - NaCl @ 20\% \\
\hline $\mathrm{T}_{9}$ - Control \\
\hline $\mathrm{SEm} \pm$ \\
\hline $\mathrm{CD}(0.05)$ \\
\hline $\mathrm{CV}(\%)$ \\
\hline
\end{tabular}

\begin{tabular}{|c|c|c|c|c|}
\hline $\begin{array}{c}\text { 2.5 per cent span } \\
\text { length }(\mathbf{m m})\end{array}$ & $\begin{array}{c}\text { Bundle strength } \\
\left(\mathrm{g} \mathrm{tex}^{-\mathbf{1}}\right)\end{array}$ & $\begin{array}{c}\text { Fineness } \\
\left(\boldsymbol{\mu g} \mathbf{~ i n c h}^{-1}\right)\end{array}$ & $\begin{array}{c}\text { Uniformity } \\
\text { ratio }\end{array}$ & $\begin{array}{c}\text { Elongation } \\
(\%)\end{array}$ \\
\hline 32.1 & 23.6 & 4.4 & 44.0 & 4.4 \\
\hline 31.3 & 23.1 & 4.6 & 44.9 & 4.1 \\
\hline 32.1 & 25.0 & 5.0 & 47.6 & 5.0 \\
\hline 32.3 & 25.7 & 5.3 & 48.0 & 5.3 \\
\hline 32.1 & 25.0 & 4.3 & 47.6 & 4.6 \\
\hline 32.0 & 25.2 & 4.6 & 46.6 & 4.6 \\
\hline 30.4 & 22.6 & 4.1 & 46.6 & 4.8 \\
\hline 30.2 & 21.4 & 4.0 & 44.6 & 4.5 \\
\hline 32.0 & 22.4 & 4.3 & 45.3 & 4.1 \\
\hline 2.76 & 2.16 & 0.24 & 4.11 & 0.28 \\
\hline $\mathrm{NS}$ & $\mathrm{NS}$ & 0.7 & $\mathrm{NS}$ & 1.1 \\
\hline 15.1 & 15.7 & 9.6 & 15.4 & 10.6 \\
\hline
\end{tabular}


Table.1 Crop calendar, temperature regimes and degree days during crop season

\begin{tabular}{l} 
Parameters \\
Date of sowing \\
Date of defoliant spray \\
\hline Boll opening percentage $(\%)$ at Defoliation \\
\hline Degree-days $\left({ }^{\circ} \mathrm{C}\right.$ day) from sowing to defoliant \\
application \\
\hline Degree-days $\left({ }^{\circ} \mathrm{C}\right.$ day) from sowing to harvest \\
\hline Degree-days $\left({ }^{\circ} \mathrm{C}\right.$ day) during defoliation process (15 \\
days after defoliant spray) \\
Average maximum temperature during defoliation \\
Average minimum temperature during defoliation
\end{tabular}

Cotton crop

$21^{\text {st }}$ July, 2016

$2^{\text {st }}$ December, 2016

60

3075 (21-07-2016 to 23-12-2016)

3616.5 (21-07-2016 to 21-01-2017)

270.7 (23-12-2016 to 07-01-2017)

32.1 (23-12-2016 to 07-01-2017)

17.7 (23-12-2016 to 07-01-2017)
The primary task of an efficient defoliation programme is timely harvest and no loss in yield and fibre quality. The defoliant efficiency is highest when moisture level of leaves is high, and when both temperature and humidity are high. These conditions were fully met in the experiment at the time of defoliant application.

These results verify the earlier findings on cotton defoliation with respect to thidiazuron (Malik et al., 1991; Malik and Din, 1997). The most important factor to be considered in the practice of chemical defoliation is the stage of crop maturity. The time of defoliation in present study coincided with the cut out phase of cotton crop.

Maximum seed cotton yield $\left(2359 \mathrm{~kg} \mathrm{ha}^{-1}\right)$ was obtained with Etherel @ 2000 ppm $\left(\mathrm{T}_{4}\right)$ and it was on par with all the other treatments except $\mathrm{NaCl} @ 15 \%\left(\mathrm{~T}_{7}\right)\left(1975 \mathrm{~kg} \mathrm{ha}^{-1}\right)$ and control $\left(\mathrm{T}_{9}\right)\left(1829 \mathrm{~kg} \mathrm{ha}^{-1}\right)$.

There was a significant increase in seed cotton yield compared to control $\left(\mathrm{T}_{9}\right)$ by 28.1 , 26.1, 23.8, and $20.9 \%$ with Etherel @ 2000 ppm $\left(\mathrm{T}_{4}\right)$, Etherel @ 1500 ppm $\left(\mathrm{T}_{3}\right)$, Dropp Ultra 540 SC (Thidiazuron 360 + Diuron 180) @ $200 \mathrm{ml} \mathrm{ha}^{-1}\left(\mathrm{~T}_{2}\right)$ and Dropp Ultra $540 \mathrm{SC}$ (Thidiazuron $360+$ Diuron 180) @ $150 \mathrm{ml}$ $\mathrm{ha}^{-1}\left(\mathrm{~T}_{1}\right)$, respectively (Table 2 ).
Kerby (1988) stated that with stimulation of defoliation process, leaves transport most of their nutrients and metabolites to developing bolls. Cotton end use depends on fibre quality. Any agronomic practice, which brings deterioration in fibre quality is not desirable. Data presented in Table 3, shows no deleterious effects of the defoliants on fibre quality.

Brown and Hyer (1956) reported that adverse effects of defoliants and desiccants are limited to those bolls that are less than 35 days old. Further, environment accounted more in fibre quality variations than defoliants. Results from this study indicate that defoliants did not cause yield loss or deterioration in fibre quality in a physiologically matured crop (Table 3).

It can be concluded that cotton under high density planting 60\% open boll may be sprayed with defoliants without loss in seed cotton and fibre quality. The atmospheric minimum and maximum temperatures of 17.7 and $32.1{ }^{\circ} \mathrm{C}$ were found conducive for inducement of defoliation process.

\section{References}

Brown, L.C. and A.H. Hyer, 1956. Chemical defoliation of cotton: Effects of 
premature defoliant and dessicant treatments on boll components, fibre properties, germination and yield of cotton. Agronomy Journal. 48: 50-5.

Cathey, G.W. 1985. Conditioning cotton for increased response to defoliant chemicals. Field Crop Research. 10: $347-53$.

Cathey, G.W. 1986. Physiology of defoliation in cotton production. In: J.R. Mauney and J.M. Stewart (Eds.), Cotton Physiology. pp: 143-54. The Cotton Foundation, Memphis, T.N. USA.

Gwathmey, C.W. and R. Hayes, 1997. Harvest aid interactions under different temperature regimes in field grown cotton. Journal of Cotton Science. 1: 19.

Kerby, T.A. 1988. Cotton physiology and cotton harvest aid. Cotton Consultant Conference. pp: 1-7. ICI. America Inc.

Malik, M.N. and Din, S. 1997. Efficacy of thidiazuron defoliant in cotton cultivars varying in maturity. The Pakistan Cottons. 41: 36-42.

Malik, M.N., Din, S and Makhdum, M.I. 1991. Accelerated boll dehiscence with thidiazuron. Tropical Agriculture. 68: $149-50$.

Snipes, C.E., and C.C. Baskin. 1994. Influence of early defoliation on cotton yield, seed quality, and fibre properties. Field Crop Research. 37:137-143.

Suttle, J.C. 1985. Involvement of ethylene in the action of the cotton defoliant thidiazuron. Plant Physiology. 78: 2726.

\section{How to cite this article:}

Kancheti Mrunalini, M. Sree Rekha and Murthy, V.R.K. 2018. Effectiveness of Harvest - Aid Defoliants and Environmental Conditions in High Density Cotton. Int.J.Curr.Microbiol.App.Sci. 7(02): 2312-2316. doi: https://doi.org/10.20546/ijcmas.2018.702.280 